\title{
Oxygenation zones in conventional and split earthen catfish ponds in eastern Arkansas
}

\author{
John C. Farrelly ${ }^{1}$, Yushun Chen ${ }^{1,2, *}$, Christopher Laskodi ${ }^{1}$
}

${ }^{1}$ Aquaculture and Fisheries Center, University of Arkansas at Pine Bluff, 1200 N. University Dr., Slot 4912, Pine Bluff, Arkansas 71601, USA

${ }^{2}$ Institute of Hydrobiology, Chinese Academy of Sciences, 7 South Donghu Road, Wuhan, Hubei 430072, China

*Correspondence: Yushun Chen at yushunchen@ihb.ac.cn, 86-27-68780161. 


\section{ABSTRACT}

Dissolved oxygen (DO) is one of the most important water quality variables associated with catfish culture. Understanding the oxygen dynamics in commercial catfish aquaculture ponds is important for understanding when oxygen problems could arise throughout the growing season. Oxygenation zones (OZ, here defined as the area with DO reaching $2.5 \mathrm{mg} / \mathrm{L}$ or greater) in both conventional (CP) and split (SP) earthen ponds were determined and compared in July and August, 2013. Hach Hydrolab data sondes were placed in the ponds, and DO concentrations were measured hourly from 9:00 PM to 9:00 AM for three consecutive nights. Variables including $\mathrm{OZ}$ volume, total DO mass in $\mathrm{OZ}, \mathrm{kg}$ of $\mathrm{DO} / \mathrm{m}^{3}$, fish density in $\mathrm{OZ}$, and $\mathrm{kg}$ of fish $/ \mathrm{m}^{3}$ in the OZ, and DO isopleths were determined using average DO concentrations. The smallest sizes or lowest volumes of the OZs occurred at 5:00 AM in both systems. The OZ volumes at 5:00 AM showed no significant difference between systems in both months. The entire fish zone was completely oxygenated in August in the SP ponds. The CP system was considered completely oxygenated at both 12:00 AM and 9:00 AM in both months, and the OZ volumes were significantly larger than those in the SP system at the same time slots. The fish density and $\mathrm{kg}$ of fish $/ \mathrm{m}^{3}$ in the OZ reached the highest at 5:00 AM in both systems in both months but without system difference. These results could help farmers evaluate the overall water quality performance of the two pond production systems. 


\section{Introduction}

The catfish industry first began in the United States in the 1960s (Engle, 2003). Catfish was fifth on the U.S. top ten list of seafood consumed in 2000 and has now fallen to seventh on the list (Hanson and Sites, 2013). The industry peaked in 2003 when it produced close to 300 million kilograms of round weight catfish; however, ever since then it has been on a downward trend (Hanson and Sites, 2011). By 2012, less than 136 million kilograms of catfish was being produced (Hanson and Site, 2013). Several factors including feed prices peaking at $\$ 562 /$ ton in August 2012, competition with imports, which account for $78 \%$ of all frozen fillet sales in the U.S., and the decrease in market catfish prices could be contributing to the current state of the industry (Hanson and Sites, 2013).

Many techniques have been developed for growing catfish throughout the maturation process of the industry. For instance, maintaining adequate water quality in production ponds is vital to high overall production. Many water quality variables can directly influence catfish aquaculture. For example, dissolved oxygen (DO), which is considered one of the most important variables, has been shown to affect the growth (Andrews et al., 1973; Carlson et al., 1980), feeding rate (Carlson et al., 1980; Torrans, 2005; Torrans, 2008; Green and Rawles, 2011), net yield (Torrans, 2005; Green and Rawles, 2011), individual weight of fish (Torrans, 2005; Green and Rawles, 2011), feed conversion ratio (FCR) (Andrews et al., 1973; Torrans, 2005), and mortality in extreme DO depletion events (Torrans, 2005). The industry has also been using hybrid catfish, a male blue catfish Ictalurus furcatus crossed with a female channel catfish I. punctatus, for years as a way to stay competitive within the aquaculture industry. Hybrid catfish have been shown to tolerate DO depletions better, have higher mean individual weight, lower FCRs, higher production in some circumstances, higher nugget yield, lower fillet fat, and 
have better fillet yield and dress-out percentage (Dunham et al., 1983; Argue et al., 2003; Li. et al., 2004; Green and Rawles, 2011). While there are many benefits to using hybrid catfish, the net yield of channel catfish and hybrid catfish grown under similar conditions did not show significant differences (Green and Rawles, 2011).

Along with maintaining adequate water quality and using hybrid catfish to continue to remain competitive, catfish farmers in the Southern United States are also implementing new production systems to combat the problems currently facing the industry. Traditionally, earthen catfish ponds were very large reaching up to 16 ha in size (Hargreaves and Tucker, 2003). However, with the discovery that smaller ponds enhanced feeding, disease control, water quality management, and other activities in catfish production, ponds have decreased in size, and most ponds built now range from $4-5$ ha (Hargreaves and Tucker, 2003). Conventional ponds (CP) use aeration rates of roughly 2.76 to $3.68 \mathrm{~kW} / \mathrm{ha}$ (Tucker, 2005). In addition to the CP systems and other production systems, an innovative catfish production system called the "split-pond" (SP) was developed at Mississippi State University and has been an attractive alternative for catfish farmers in the Southern U.S. in recent years. Split ponds are typically constructed by dividing a conventional earthen pond into two sections, an algal growth basin or waste treatment area (about $80 \%$ of the total area) and a fish-holding area (20\% of the total area). Typically, in the split-pond system, fish density is five times that of conventional catfish ponds (Tucker, 2009). Split ponds were developed as an alternative to the partitioned aquaculture system developed at Clemson University. However, the premise of the split-ponds is the same. A smaller zone will hold the fish, and the larger waste area will treat fish waste and produce oxygen during the day through photosynthesis. In split-pond systems, good fish production, high feeding rates, and low feed conversions are the norm (Tucker, 2009). For example, in a 2009 
study of a commercial split-pond, $17,880 \mathrm{~kg} / \mathrm{ha}$ of fish were produced with a FCR of 1.83

(Tucker, 2009). The daily feeding rates averaged $162 \mathrm{~kg} / \mathrm{ha}$ and the maximum daily feeding rate averaged $250 \mathrm{~kg} / \mathrm{ha}$ from the end of August through September (Tucker, 2009). From a nine-year study in experimental and commercial split-ponds, net catfish production ranged from 17,000 to close to 20,000 kg/ha and had FCRs below 2.0 (Tucker, 2009). The split-pond system has been tested, and there is an increasing trend of applications in commercial ponds in the Mississippi Delta. We have compared occurrences of growth-affecting DO and ammonia in these different culture systems in previous studies (e.g., Farrelly et al., 2015). However, we are still not clear on the DO dynamics and distribution in these systems, which will be very useful in evaluating the overall water quality performance and understanding DO limitations in these systems.

Thus, the objective of this study was to determine and compare oxygenated zones of conventionally operated and split-pond production systems. Results of this study may aid farmers in deciding which production system is better for their farm in the current catfish industry.

\section{Materials and Methods}

\subsection{Experimental ponds and fish stocking}

Two split ponds (SP) and two conventional earthen ponds (CP) in eastern Arkansas were selected for this study. Mean sizes of the ponds were $2.8 \pm 0.0$ and $3.24 \pm 0.0$ ha for the SP and CP systems, respectively. The stocking densities for the SP and CP systems were $30,672 \pm 1831$ and 14,742 \pm 234 fish/ha. Both the CP and SP systems were equipped with three regular 10-hp paddlewheel aerators. Aeration rates were $35.0 \pm 0.0$ and $6.9 \pm 0.0 \mathrm{~kW} / \mathrm{ha}$ for the $\mathrm{SP}$ and $\mathrm{CP}$ systems, respectively. Aeration rates and stocking densities for the SP system were calculated 
using only the size of the fish zone. Detailed information of the individual ponds used is presented in Table 1.

\subsection{Data sondes set-up and data collection}

An area of water was considered to be in the oxygenation zone (OZ) if its DO was $2.5 \mathrm{mg} / \mathrm{L}$ or greater. The OZs were quantified twice for each system in July and August, 2013. The ponds were sampled in an alternating fashion (i.e. SP-1, CP-1, SP-2, and CP-2). DO was measured at $40 \mathrm{~cm}$ below the surface from 9:00 pm to 9:00 am by using Hydrolab DS5X Multivariablesonde (HachHydromet ${ }^{\circledR}$ ) data loggers. Data loggers were held in place by a 3.66-m steel pipe driven into the pond bottom with a sledgehammer. Another $0.61-\mathrm{m}$ pipe with a $0.3-\mathrm{m}$ chain welded to it was attached to an adjustable piece of metal that was attached to the original 3.66-m pipe.

Depending on how deep the 3.66-m pipe was driven into the pond bottom, an adjustable piece of metal could be moved up or down to set the DO probe of the data logger at $40 \mathrm{~cm}$ below the surface.

The fish zone of each split pond was measured and marked with stakes to spread the Hydrolab data loggers out in a grid formation. For example, the fish zone in SP-2 was measured to be roughly $80-\mathrm{m}$ by $80-\mathrm{m}$. Two rows of data loggers were placed at $40 \%$ and $80 \%$ of the distance

from the shore where the aerators were placed. The two rows of data loggers were placed at 31.2 $\mathrm{m}$ and $62.4 \mathrm{~m}$ from the aerators side, respectively (Figure 1). The three columns of data loggers were placed at every $20 \mathrm{~m}$ across the pond, which was $25 \%$ of the total distance across the pond (Figure 1). Stakes were placed along the sides of the banks where data loggers were to be placed (at the previously mentioned measurements). Rope was attached to a stake and connected to the stake on the opposite bank with the rope over the water. The data loggers were placed at the intersection of the ropes (Figure 1). The data loggers were left in the fish zone of the split ponds 
for three nights and two days. DO concentrations were recorded from 9:00 PM until 9:00 AM each day. Data loggers were cleaned and in regular maintenance after each three-day deployment to avoid fouling from sediment and algae.

A similar procedure was followed for placement of data loggers in the CP system (Figure 2). Three aerators were located in the corner in each CP pond. The data loggers were arranged as follows: two columns were placed in front of the aerators and moving out towards the far shore. The outside column was placed on the outside edge of the third aerator (aerator situated closer to the center of the pond). This was at $42.7 \mathrm{~m}$ from the shore to the right of the aerators. The inside row of aerators was placed halfway between the outer row and the shore at $21.3 \mathrm{~m}$. From the shore behind the aerators to the opposite shore, the total length was roughly $183 \mathrm{~m}$, therefore rows were placed every $45 \mathrm{~m}$ (i.e. $45 \mathrm{~m}, 90 \mathrm{~m}, 135 \mathrm{~m}$ ) (Figure 3) moving away from the aerators. The data loggers were left in this arrangement for three nights and two days recording DO from 9:00 PM to 9:00 AM. Once it was determined the outside column was in the $\mathrm{OZ}$ (DO > 2.5 $\mathrm{mg} / \mathrm{L}$ ) then the inside column of data loggers became the new outside row and was placed at 64 $\mathrm{m}$ from the shore to the right of the aerators and left for another three nights recording DO concentrations from 9:00 PM to 9:00 AM. This movement continued until the outside row experienced DO levels less than $2.5 \mathrm{mg} / \mathrm{L}$ at 5:00 am. The same distances were done for CP-2; however, the aerators were slightly closer together, so the data loggers were not positioned exactly on the outside edge of the aerators. Flow of the OZs was taken next to each data logger in the morning of the third day. The data loggers were in the pond at $40 \mathrm{~cm}$ below the surface right next to the DO probe. However, only the flow taken next to data loggers in the OZs is presented in the results section.

\subsection{Data Analyses}


For the $\mathrm{OZ}$ analysis, first, the DO concentrations were averaged over the three nights at each hour for determination of $\mathrm{OZ}$ metrics. To obtain an accurate estimation, each pond was divided into spatial cells for DO averages. If a cell only contained one data logger, the DO concentrations from only that data logger was used for that cell (e.g. Cell 1; Figure 2). If a cell touched two or more data loggers, the DOs from all data loggers were used to average that cell (e.g. 2 loggers in Cell 2, 4 loggers in Cell 6; Figure 2). The CP system OZs were calculated similarly to the fish zone of the SP system. Each cell had an average DO concentration from corresponding data loggers from the three nights. If the outside column at 5:00 AM was determined to be outside the $\mathrm{OZ}$ but at 12:00 AM and 9:00 AM the outside column was still above $2.5 \mathrm{mg} / \mathrm{L}$, then the rest of the pond was considered to be in the $\mathrm{OZ}$.

The metrics calculated for the $\mathrm{OZ}$ included the $\mathrm{OZ}$ volume $\left(\mathrm{m}^{3}\right)$, total $\mathrm{DO}$ mass in the $\mathrm{OZ}$ $(\mathrm{kg}), \mathrm{kg}$ of $\mathrm{DO} / \mathrm{m}^{3}$ in the $\mathrm{OZ}$, fish density in the $\mathrm{OZ}\left(\mathrm{fish} / \mathrm{m}^{3}\right)$, and $\mathrm{kg}$ of fish $/ \mathrm{m}^{3}$ in the $\mathrm{OZ}$. These metrics were determined for the time slots of 12:00 AM (middle night), 5:00 AM (before sunrise), and 9:00 AM (after sunrise) for all ponds in both months. The metric of the OZ volume was determined by calculating the volume in each cell with length $\times$ width $\times$ height. If a cell was not fully oxygenated, only the volume of the oxygenated area was determined. All cells that had oxygenated area were then added together to get total volume. Total DO mass in the $\mathrm{OZ}$ was determined by multiplying above mentioned DO concentration $(\mathrm{mg} / \mathrm{L})$ in a cell by the total cubic meters of oxygenated water in that cell and converted to $\mathrm{kg}$ of DO. The $\mathrm{kg}$ of $\mathrm{DO} / \mathrm{m}^{3}$ in the $\mathrm{OZ}$ was determined by converting the above mention DO from $\mathrm{mg} / \mathrm{L}$ to $\mathrm{kg} / \mathrm{L}$ and dividing it by the total cubic meters. The fish density in the $\mathrm{OZ}$ was determined by dividing the total number of fish in the pond by the total liters in the OZ. The total number of fish in each pond was determined by dividing the survival of each pond by the number of days the system was in 
production and then multiplying that by the number of days before the date that the data loggers were in the pond. The survival of the two conventional ponds was not available, so adjusted survival rates of $70 \%, 80 \%$ and $90 \%$ were used. These numbers were used to get a representative range of possible survival rates in catfish ponds in the study area. The $\mathrm{kg}$ of fish $/ \mathrm{m}^{3}$ in the OZ was determined by dividing the $\mathrm{kg}$ of fish in that pond by the total cubic meters in the OZ. The $\mathrm{kg}$ of fish in each pond was determined by calculating the growth per day of the entire pond, by dividing the harvest weight by the number of days in each pond was in production. The $\mathrm{kg}$ of fish in the pond at the time the data loggers were in each individual pond was determined, by multiplying growth per day by the number of days the pond was in production up until the day the data loggers were put in the ponds.

One-way ANOVAs were used to compare the metrics described above among the systems and between the two sampling months. Statistical difference was determined when $P<0.05$. Isopleth maps were drawn manually to show the sizes and patterns of the OZs in different production systems.

\section{Results}

\subsection{The OZ volume}

Mean metrics for the OZs of the SP and CP systems for July and August are presented in Table 2. At 5:00AM in both July and August, the OZ volumes did not show significant difference between the two systems $(P>0.05)$. The CP ponds were fully oxygenated in both months at the three time points except one pond at 5:00 AM in July (Figure 3). In the SP system, the OZ volume at 5:00 AM in July ranged from 5,700 to 7,500 $\mathrm{m}^{3}$. In July, the SP fish zone was not completely oxygenated at 5:00 AM in both ponds (Figure 4, only one pond's OZ was showed 
as an example), and at 12:00 AM (Figure 5) and 9:00 AM (Figure 6) in one pond. In the CP system at 5:00 AM in July, the OZ volume ranged from 7,500 to 9,700 $\mathrm{m}^{3}$. In August, both pond systems showed an increase in the OZ volumes at 5:00 AM. In the SP system, the OZ volume at 5:00 AM in August ranged from 12,000 to $12,500 \mathrm{~m}^{3}$, which was significantly larger than that in July (Table 2). The CP system also showed an increase in August as the OZ volume at 5:00 AM and ranged from 8,500 to $11,200 \mathrm{~m}^{3}$. In August, the entire fish zone in both SP ponds was completely oxygenated ( $\mathrm{DO}>2.5 \mathrm{mg} / \mathrm{L})$.

\subsection{The fish density in the $O Z$}

The fish density in the OZ changed at the different sampling times. In July, the mean fish density at 5:00 AM in the SP systems was $12.2 \pm 2.2 \mathrm{fish} / \mathrm{m}^{3}$ while the $\mathrm{CP}$ systems at 5:00 AM had roughly $5.1 \pm 1.0 \mathrm{fish} / \mathrm{m}^{3}$. This was not significantly different between systems but the SP system held $82 \%$ more fish in the OZ. At the $70 \%$ survival rate, the mean fish density in the $\mathrm{CP}$ system decreased to $4.7 \pm 0.9 \mathrm{fish} / \mathrm{m}^{3}$. At the $90 \%$ survival rate, the fish density increased to 5.4 $\pm 1.1 \mathrm{fish} / \mathrm{m}^{3}$. At both of these survival rates, the fish density was not significantly different between the systems. The fish density was significantly higher in the SP system at 12:00 AM and 9:00 AM compared to the CP system at those same times. In August, there was a decrease in fish density in the $\mathrm{OZ}$ at the 5:00 AM sampling event in both systems. The SP system had 6.1 \pm $0.1 \mathrm{fish} / \mathrm{m}^{3}$ and the CP system had $4.3 \pm 0.8$, which was not significantly different between systems. Using the $70 \%$ and $90 \%$ survival rates, the fish density decreased to $3.9 \pm 0.7$ and increased to $4.6 \pm 0.8 \mathrm{fish} / \mathrm{m}^{3}$, respectively. Similar to July, the fish density at 12:00 AM and

9:00 AM was significantly different between the systems. In August, the OZ of the SP system held just 34\% more fish than the CP system's OZ.

\subsection{The total $\mathrm{kg}$ fish $/ \mathrm{m}^{3}$ of the $\mathrm{OZ}$}


The total $\mathrm{kg}$ fish $/ \mathrm{m}^{3}$, similar to the fish density, changed at the different sampling times due to changing OZ size. At 5:00 AM in July, the $\mathrm{kg}$ fish $/ \mathrm{m}^{3}$ for the SP and CP systems was 3.9 \pm 1.5 and $1.7 \pm 0.5 \mathrm{~kg} / \mathrm{m}^{3}$, respectively. They were not significantly different, although the SP system did have 78\% more $\mathrm{kg}$ of fish in the OZ. At 5:00 AM in August, the mean $\mathrm{kg}$ fish $/ \mathrm{m}^{3}$ for the SP system declined to $2.6 \pm 0.4$ while the CP system mean increased slightly to $1.8 \pm 1.3 \mathrm{~kg}$ fish $/ \mathrm{m}^{3}$. The SP systems held just $36 \%$ more $\mathrm{kg}$ fish $/ \mathrm{m}^{3}$ than the CP system in August. Similar to the fish density, the $\mathrm{kg}$ fish $/ \mathrm{m}^{3}$ was significantly different at 12:00 AM and 9:00 AM between the two systems in both July and August. Mean $\mathrm{kg}$ fish $/ \mathrm{m}^{3}$ of the SP systems in July held $156 \%$ and 160\% higher at 12:00 AM and 9:00 AM, respectively.

\subsection{Flow within the $\mathrm{OZ}$}

The flow within the OZ of the SP system was higher than the flow in the CP system OZ. The flow in the OZ of the CP system at 12:00 AM and 9:00 AM is considered to be zero because the whole pond was considered oxygenated. The flow at 5:00 AM in CP is the only one reported. The flow of CP systems ranged from 0.002 to $0.235 \mathrm{~m}^{3} / \mathrm{sec}$ in July and from 0.002 to 0.165 $\mathrm{m}^{3} / \mathrm{sec}$ in August. The flow catfish faced within the OZ for the SP system ranged from $0.098-$ $0.437 \mathrm{~m}^{3} / \mathrm{sec}$ in July and $0.002-0.634 \mathrm{~m}^{3} / \mathrm{sec}$ in August.

\section{Discussion}

The SP and CP systems have similar OZ volumes at the 5:00 AM sampling times. Although they were equipped with the same number of aerators and the water had the ability to disperse farther throughout the larger CP system, the OZ in the SP was actually larger in terms of the OZ volume and total mass of DO within it. The fish zone of the SP was completely oxygenated 
(entire area $>2.5 \mathrm{mg} / \mathrm{L}$ ) at all sampling times with the exception for SP-1 at 5:00 AM in July and SP-2 when at 12:00 AM, 5:00 AM, and 9:00 AM in July. This was likely caused by an exceptionally large algal bloom for SP-2. Chlorophyll $a$ data gathered from this pond one day prior to placing data loggers in the pond averaged $4874.45 \mu \mathrm{g} / \mathrm{L}$. The consumption of oxygen by this large phytoplankton bloom may have reduced oxygen in the fish zone to below $2.5 \mathrm{mg} / \mathrm{L}$. Therefore, the size of the OZ and the amount of oxygen in it shrunk, and increased the fish density and $\mathrm{kg}$ fish $/ \mathrm{m}^{3}$. Another possible explanation for the low DO in the fish zone of the SP system, particularly SP-1, could be the suspension of sediment that can cause DO depletion (Steeby et al., 2004). This resuspension of sediment could be caused by the high aeration rates in the relatively small fish zone of the SP, which could disturb the sediment and increase clay particles in water (Hollerman and Boyd, 1980). While almost every night in the fish zone of the SP system was fully oxygenated, there is a chance placement of the aerators near one of the sluiceways contributed to some loss of water with high DO. It is likely a minimal loss, but placement of aerators might have an influence on the oxygen dynamics of the OZs in the SP system. DO depletions in the fish zone of the SP system could also be the result of increased feeding rate compared to the $\mathrm{CP}$ system. Higher feeding rate is associated with longer durations of lower DO concentrations (Hargreaves and Steeby, 1999).

The OZ volume for the CP system was much higher than the SP system at both 12:00 $\mathrm{AM}$ and 9:00 AM. This was because the area of the CP system was much larger than the fish zone of the SP system. The entire CP system was assumed to be oxygenated (above $2.5 \mathrm{mg} / \mathrm{L}$ ) at those times because even the farthest data loggers from the aerators were still recording DO above the threshold. The assumption was held true due to the high levels of DO at the beginning of sampling (9:00 PM). The DO values recorded by the data loggers would not have fallen below 
the threshold in that short amount of time. This is supported by the Boyd et al. (1978) model in which their predicted and measured DO $(\mathrm{mg} / \mathrm{L})$ did not begin to approach critical levels until into the early morning hours because the decline was linear over time. The OZ volume began to decline over the night and reached the lowest levels in the early morning. This is because aeration could only provide limited oxygen to the large CP system. Fish, plankton, and sediment respiration used up DO in the un-aerated areas of the pond throughout the night. DO concentrations from data loggers far from the aerators reached levels similar in ponds without aeration (Hollerman and Boyd, 1980, Lai-Fa and Boyd, 1988). These low levels of DO are also observed on occasion in the SP system. As the OZ volume changed, all the other metrics used in this study changed accordingly. Total mass of DO and $\mathrm{kg} \mathrm{DO} / \mathrm{m}^{3}$ in the $\mathrm{OZ}$ were directly linked to how big the $\mathrm{OZ}$ was at a given sampling time.

Two of the metrics used (i.e. fish density and $\mathrm{kg}$ fish $/ \mathrm{m}^{3}$ in the OZ) assume every fish is within the OZ because fish become conditioned to find the higher DO around aerators (Boyd, 1998). This might not always be the case as some fish, especially smaller fish, may be excluded due to competition for optimal habitat (higher DO). This type of competition, which is also seen in feeding in catfish ponds (Randolph and Clemens, 1976), could be the cause for lower production in the CP systems. Smaller fish are excluded from feeding first and inhabit less than optimal habitats thereby affecting their growth. The significant differences of these two metrics at both 12:00 AM and 9:00 AM between production systems has more to do with the overall size of the pond since the entire CP system was considered oxygenated. The growth and mortality rates in each system may have also influenced the fish related metrics in the same pond systems between months. 
Mean flow the catfish faced in the fish zone of SP system was higher than what catfish faced in the CP system. While the same amount of aeration was applied to both systems, the water in the CP system had more room to disperse, thus possibly lowering the flow faced by fish. The flow increased at the data loggers that were closer to the aerators. If flow in the fish zone of the SP system was uniform from top to bottom, then respiration of the fish should increase because respiration increases with activity (Boyd and Tucker, 1998). Paddle-wheels work by slashing water into the air and can mix well oxygenated surface water into deeper water (Boyd, 1998). While the flow was higher for the catfish in the fish zone of the SP system, they might be able to avoid heavy flow while still getting oxygenated water near the bottom. Some of the flow values were lower in the current study than those reported in other split-pond studies (e.g. Brown et al. 2016). This may be because the difference of flow measurement locations as the current study took flows next to the data sondes. One limitation of the current study is only a singledepth oxygen reading was taken. If DO concentrations were sampled at multiple depths, a more complete 3-demensional pattern of oxygenation of these zones would be achievable. Another limitation is the number of the experimental ponds, which was a result of the availability of pond access, data loggers, and personnel for the study.

\section{Acknowledgements}

We want to thank Matt Recsetar for connecting us with the cooperative farmers, Nathan Stone and Lin Xie for data analysis assistance. The State of Arkansas (the 1890 State Match Fund, number 111-23-11110491) and USDA (the MRBI program, number 299-23-11110545) provided funding for the project. 


\section{References}

Andrews, J.W., Murai, T., Gibbons, G. 1973. The influence of dissolved oxygen on the growth of channel catfish. Transactions of the American Fisheries Society 102 (4), 835 - 838.

Argue, B.J., Liu, Z., Dunham, R.A. 2003 Dress-out and fillet yields of channel catfish, ictalurus punctatus, blue catfish, Ictalurusfurcatus, and their $\mathrm{F}_{1}, \mathrm{~F}_{2}$, and backcross hybrids. Aquaculture 228, $81-90$.

Boyd, C.E., Romaire, R.P., Johnson, E. 1978. Predicting early morning dissolved oxygen concentrations in channel catfish ponds. Transactions of the American Fisheries Society 107 (3), $484-492$.

Boyd, C.E. 1998. Pond water aeration systems. Aquacultural Engineering 18, 9 - 40.

Boyd, C.E., Tucker, C.S. 1998. Pond Aquaculture Water Quality Management. Springer, Norwell, Massachusetts.

Brown, T.W., Tucker, C. S., Rutland, B.L. 2016. Performance evaluation of four different methods for circulating water in commercial-scale, split-pond aquaculture systems. Aquacultural Engineering, 70, 33-41.

Carlson, A.R., Blocher, J., Herman, L.J. 1980. Growth and survival of channel catfish and yellow perch exposed to lowered constant and diurnally fluctuating dissolved oxygen concentrations. The Progressive Fish-Culturist 42(2), 73-78.

Dunham, R.A., Smitherman, R.O., Webber, C.1983. Relative tolerance of channel X blue hybrid and channel catfish to low oxygen concentraions. The Progressive Fish-Culturist 45 (1), $55-57$.

Engle, C. 2003. The evolution of farm management, production efficiencies, and current challenges to catfish production in the United States. Aquaculture Economics 7 (1/2), 67 -84 .

Farrelly, J. C., Chen, Y., Shrestha, S. 2015. Occurrences of growth related target dissolved oxygen and ammonia in different catfish pond production systems in southeast Arkansas. Aquacultural Engineering 64, 68-77.

Green, B.W., Rawles, S.D. 2011. Comparative production of channel catfish and channel catfish $\mathrm{x}$ blue hybrid catfish subjected to two minimum dissolved oxygen concentrations. North American Journal of Aquaculture 73 (3), 311 - 319.

Hanson, T., Sites, D. 2011. 2010 Catfish database. Information Report 2011 - 01.Mississippi State University, Department of Agricultural Economics.

Hanson, T., Sites, D. 2013. 2012 Catfish database. Fisheries and Allied Aquaculture Department Series No.1.Alabama Agricultural Experiment Station, Auburn, Alabama. 
Hargreaves, J.A., Steeby, J.A.1999. Factors affecting metabolism of commercial channel catfish ponds as indicated by continuous dissolved oxygen measurement. Journal of the World Aquaculture Society 30, 410-421.

Hargreaves, J.A., Tucker, C.S. 2003. Defining loading limits of static ponds for aquaculture. Aquacultural Engineering 28, $47-63$.

Hollerman, W.D., Boyd, C.E.1980. Nightly aeration to increase production of channel catfish. Transactions of the American Fisheries Society 109 (4), 446 - 452.

Lai-Fa, Z., Boyd, C.E. 1988. Nightly aeration to increase the efficiency of channel catfish production. The Progressive Fish-Culturist 50, 237 - 242.

Li, M.H., Robinson, E.H., Manning, B.B., Yant, D.R., Chatakondi, N.G., Bosworth, B.G., Wolters, W.R. 2004. Comparison of the channel catfish, Ictalurus punctatus (NWAC103 strain) and the channel $\mathrm{x}$ blue catfish, I. punctatus $\mathrm{x}$ I. furcatus, $\mathrm{F}_{1}$ hybrid for growth, feed efficiency, processing yield, and body composition. Journal of Applied Aquaculture 15 (3-4), $63-71$.

Randolph, K.N., Clemens, H.P. 1976. Some factors influencing the feeding behavior of channel catfish in culture ponds. Transactions of the American Fisheries Society 105 (6), 718 724.

Steeby, J.A., Hargreaves, J.A., Tucker, C.S., Cathcart, T.P. 2004. Modeling industry-wide sediment oxygen demand and estimation of the contribution of sediment to total respiration in commercial channel catfish ponds. Aquacultural Engineering 31, 247 - 262

Torrans, E.L. 2005. Effect of oxygen management on culture performance of channel catfish in earthen ponds. North American Journal of Aquaculture 67 (40), 275-288.

Torrans, E.L. 2008. Production responses of channel catfish to minimum daily dissolved oxygen concentrations in earthen ponds.North American Journal of Aquaculture.70 (4), 371-381.

Tucker C.S. 2005. Pond aeration.SRAC Publication No. 3700.Southern Regional Aquaculture Center.USDA, Stoneville, Mississippi.

Tucker, C.S. 2009. Southern regional aquaculture center: Twenty-second annual progress report. Southern Regional Aquaculture Center, USDA, Stoneville Mississippi. 
Table 1.- Individual pond descriptions. SP: split ponds, CP: conventional ponds

\begin{tabular}{lllllc}
\hline $\begin{array}{l}\text { Production } \\
\text { system }\end{array}$ & $\begin{array}{l}\text { Area } \\
\text { (ha) }\end{array}$ & $\begin{array}{l}\text { Aeration rate } \\
\text { (kW/ha)* }\end{array}$ & $\begin{array}{l}\text { Stocking } \\
\text { density } \\
\text { (fish/ha)* }\end{array}$ & $\begin{array}{l}\text { Weight } \\
\text { stocked } \\
\text { (kg/pond) }\end{array}$ & Date stocked \\
\hline SP-1 & 2.79 & 35.5 & 31,967 & 3955 & $4 / 8 / 2013$ \\
SP-2 & 2.79 & 35.5 & 29,377 & 3638 & $4 / 8 / 2013$ \\
CP-1 & 3.24 & 6.9 & 14,908 & 5237 & $3 / 1 / 2013$ \\
CP-2 & 3.24 & 6.9 & 14,576 & 5570 & $3 / 6 / 2013$ \\
\end{tabular}

*Aeration rates and stocking density in the SP systems were calculated based on the fish zone area. 
Table 2.-Differences in oxygenation zone (OZ) metrics in the SP and CP systems in different months. Letters a and b represent significant differences between the different systems in the same month at the same time (i.e. SP vs CP at 12:00 AM in July). Letters x and y represent significant differences between different months in the same system at the same times (i.e. SP at 12:00 AM in July vs August). Statistical difference was determined when $P<0.05$. SP: split ponds, CP: conventional ponds

\begin{tabular}{|c|c|c|c|c|c|c|}
\hline \multirow{3}{*}{ "OZ" Metrics } & \multicolumn{6}{|c|}{ July } \\
\hline & \multicolumn{3}{|c|}{$\mathrm{SP}$} & \multicolumn{3}{|c|}{$\mathrm{CP}$} \\
\hline & 12:00 AM & 5:00 AM & 9:00 AM & 12:00 AM & 5:00 AM & 9:00 AM \\
\hline OZ volume $\left(\mathrm{m}^{3}\right)$ & $10,600 \pm 1,700 \mathrm{a}$ & $6,600 \pm 1,300 x$ & $\begin{array}{l}10,000 \pm \\
2,500 \mathrm{a}\end{array}$ & $50,200 \pm 1,500 b$ & $8,600 \pm 1,600$ & $50,200 \pm 1,500 \mathrm{~b}$ \\
\hline $\begin{array}{l}\text { Total DO mass } \\
\text { in } \mathrm{OZ}(\mathrm{kg})\end{array}$ & $35.19 \pm 10.59 \mathrm{a}$ & $19.47 \pm 4.74 \mathrm{x}$ & $33.06 \pm 10.17 \mathrm{a}$ & $177.08 \pm 28.53 b$ & $23.72 \pm 4.76$ & $160.22 \pm 40.66 b$ \\
\hline $\mathrm{Kg}$ of $\mathrm{DO} / \mathrm{m}^{3}$ & $0.004 \pm 0.0004$ & $0.003 \pm 0.0001$ & $0.003 \pm 0.0002 x$ & $0.004 \pm 0.0005$ & $0.003 \pm 0.00004$ & $0.003 \pm 0.0007$ \\
\hline $\begin{array}{l}\text { Fish density } \\
\left(\text { fish } / \mathrm{m}^{3}\right)\end{array}$ & $7.45 \pm 1.1$ & $12.1 \pm 2.2$ & $8.0 \pm 1.9 \mathrm{a}$ & $0.86 \pm 0.04$ & $5.1 \pm 1.0$ & $0.86 \pm 0.04$ \\
\hline $\mathrm{Kg}$ fish $/ \mathrm{m}^{3}$ & $2.4 \pm 0.8 \mathrm{a}$ & $3.9 \pm 1.5$ & $2.7 \pm 1.1 \mathrm{a}$ & $0.3 \pm 0.1 \mathrm{~b}$ & $1.7 \pm 0.5$ & $0.3 \pm 0.1 \mathrm{~b}$ \\
\hline
\end{tabular}


Table 2 (continued)

\begin{tabular}{|c|c|c|c|c|c|c|}
\hline \multirow[t]{3}{*}{ "OZ” Metrics } & \multicolumn{6}{|c|}{ August } \\
\hline & \multicolumn{3}{|c|}{$\mathrm{SP}$} & \multicolumn{3}{|c|}{$\mathrm{CP}$} \\
\hline & 12:00 AM & 5:00 AM & 9:00 AM & 12:00 AM & 5:00 AM & 9:00 AM \\
\hline OZ volume $\left(\mathrm{m}^{3}\right)$ & $12,300 \pm 330 \mathrm{a}$ & $12,300 \pm 330 y$ & $12,300 \pm 330 a$ & $50,600 \pm 3,100 b$ & $9,800 \pm 1,900$ & $50,600 \pm 3,100 b$ \\
\hline $\begin{array}{l}\text { Total DO mass } \\
\text { in OZ }(\mathrm{kg})\end{array}$ & $64.18 \pm 7.52 \mathrm{a}$ & $45.29 \pm 6.68 \mathrm{y}$ & $49.61 \pm 3.14 \mathrm{a}$ & $184.74 \pm 7.60 \mathrm{~b}$ & $30.56 \pm 7.31$ & $150.35 \pm 1.57 \mathrm{~b}$ \\
\hline $\mathrm{Kg}$ of $\mathrm{DO} / \mathrm{m}^{3}$ & $0.005 \pm 0.0005 \mathrm{a}$ & $0.004 \pm 0.0004$ & $0.004 \pm 0.0001$ ay & $0.004 \pm 0.000007 \mathrm{~b}$ & $0.003 \pm 0.0001$ & $0.003 \pm 0.0002 b$ \\
\hline $\begin{array}{l}\text { Fish density } \\
\left(\text { fish } / \mathrm{m}^{3}\right)\end{array}$ & $6.1 \pm 0.09 \mathrm{a}$ & $6.1 \pm 0.09$ & $6.1 \pm 0.09 \mathrm{a}$ & $0.83 \pm 0.04 \mathrm{~b}$ & $4.3 \pm 0.8$ & $0.83 \pm 0.04 \mathrm{~b}$ \\
\hline $\mathrm{Kg}$ fish $/ \mathrm{m}^{3}$ & $2.6 \pm 0.4 \mathrm{a}$ & $2.6 \pm 0.4$ & $2.6 \pm 0.4 \mathrm{a}$ & $0.34 \pm 0.2 b$ & $1.8 \pm 1.3$ & $0.34 \pm 0.2 b$ \\
\hline
\end{tabular}




\section{Figure captions}

Figure 1.Hydrolab data loggers (round dots) placement in fish zone of split-ponds. Arrows represent where water leaves and enters the fish zone during the day. The three Xs indicate aerators. The fish zone was divided into spatial cells to quantify oxygenation zones.

Figure 2.Hydrolab data loggers (round dots) placement in conventional ponds. The three Xs indicate aerators. The whole pond was divided into spatial cells to quantify oxygenation zones.

Figure 3.Oxygenation zone pattern for Conventional Pond 1 at 5:00 AM in July.

Figure 4.Oxygenation zone pattern for Split Pond 2 at 5:00 AM in July. Large arrows represent the inflow and outflow of the split pond sluiceways.

Figure 5.Oxygenation zone pattern for Split Pond 2 at 12:00 AM in July. Large arrows represent the inflow and outflow of the split pond sluiceways.

Figure 6.Oxygenation zone pattern for Split Pond 2 at 9:00 AM in July. Large arrows represent the inflow and outflow of the split pond sluiceways. 


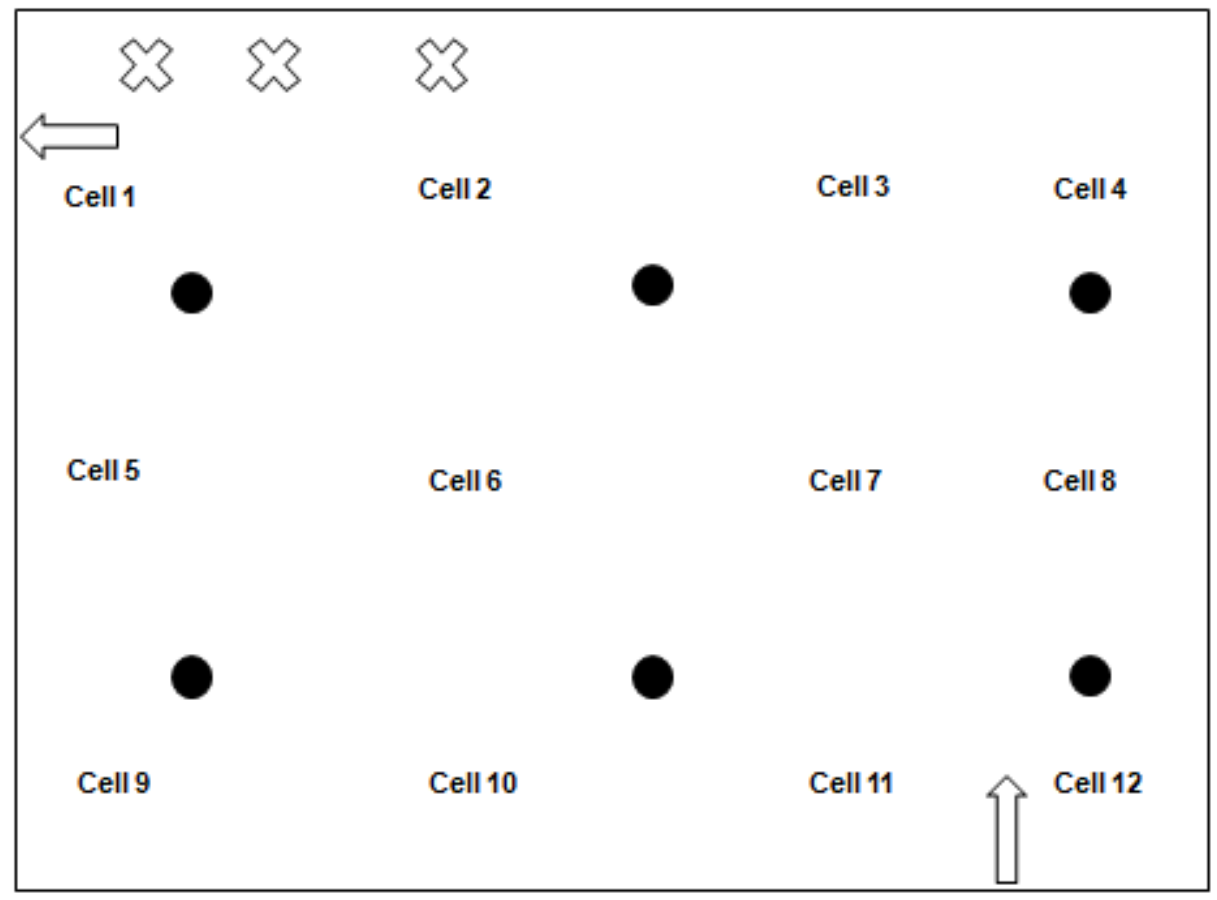

Figure 1.Hydrolab data loggers (round dots) placement in fish zone of split-ponds. Arrows represent where water leaves and enters the fish zone during the day. The three Xs indicate aerators. The fish zone was divided into spatial cells to quantify oxygenation zones. 


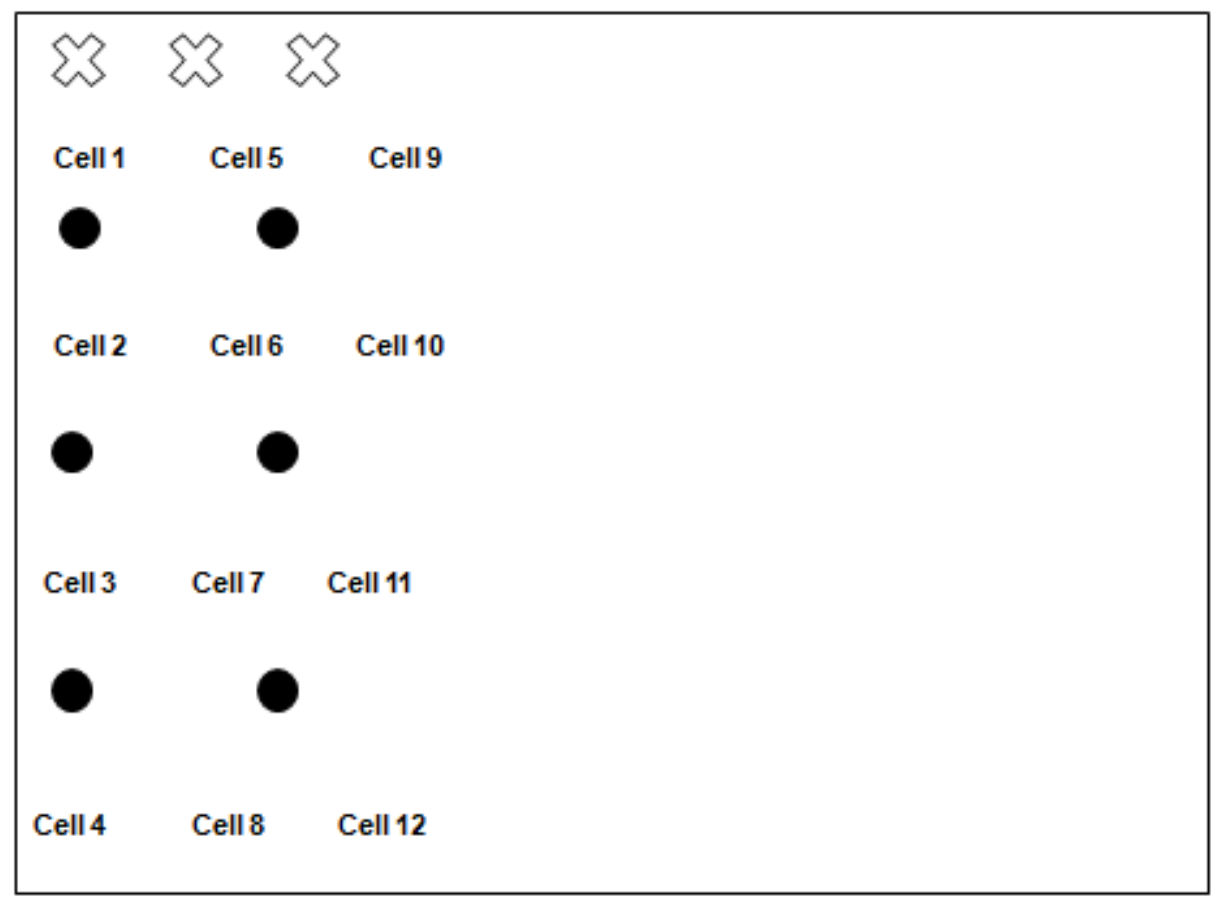

Figure 2.Hydrolab data loggers (round dots) placement in conventional ponds. The three Xs indicate aerators. The whole pond was divided into spatial cells to quantify oxygenation zones. 


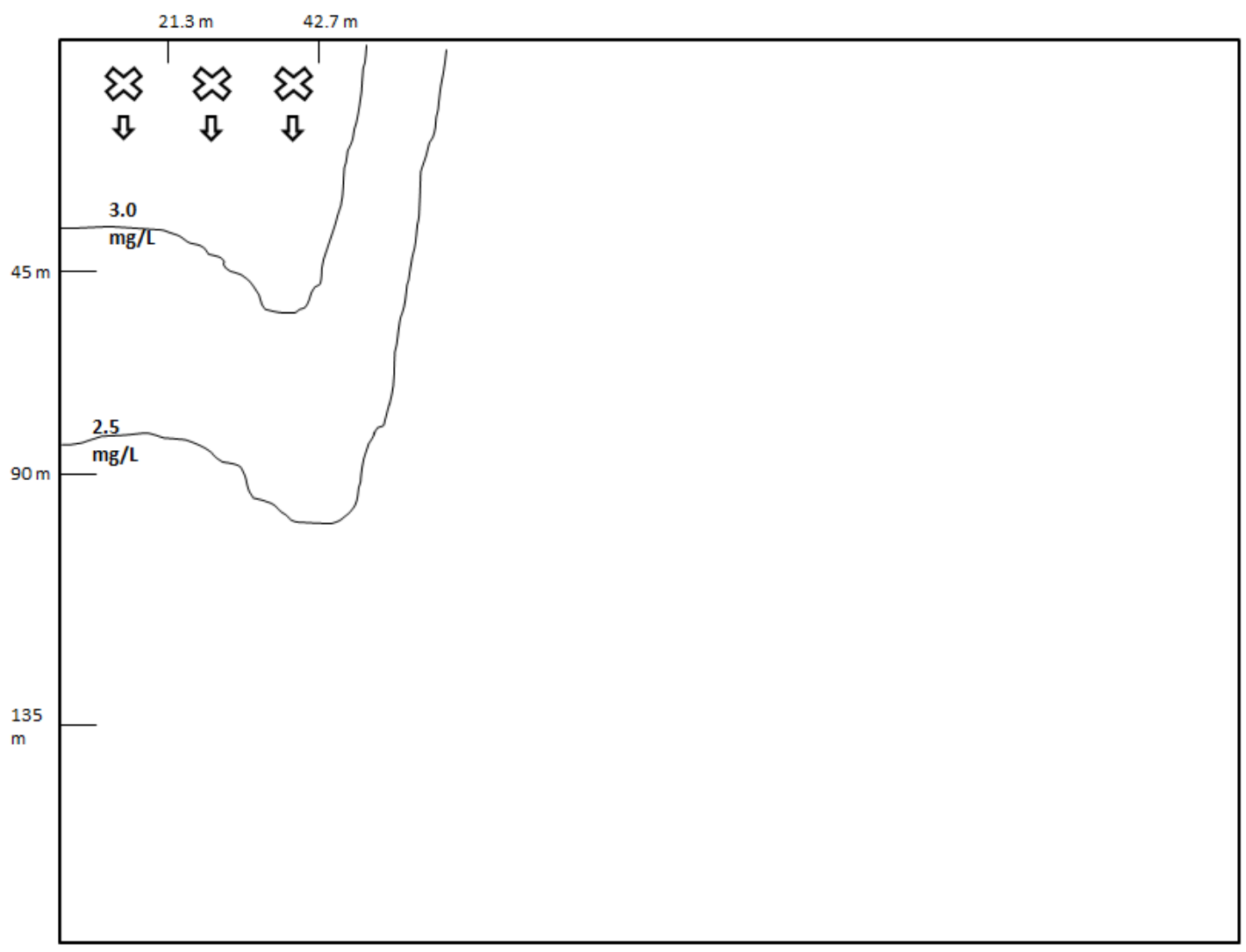

Figure 3.Oxygenation zone pattern for Conventional Pond 1 at 5:00 AM in July. 


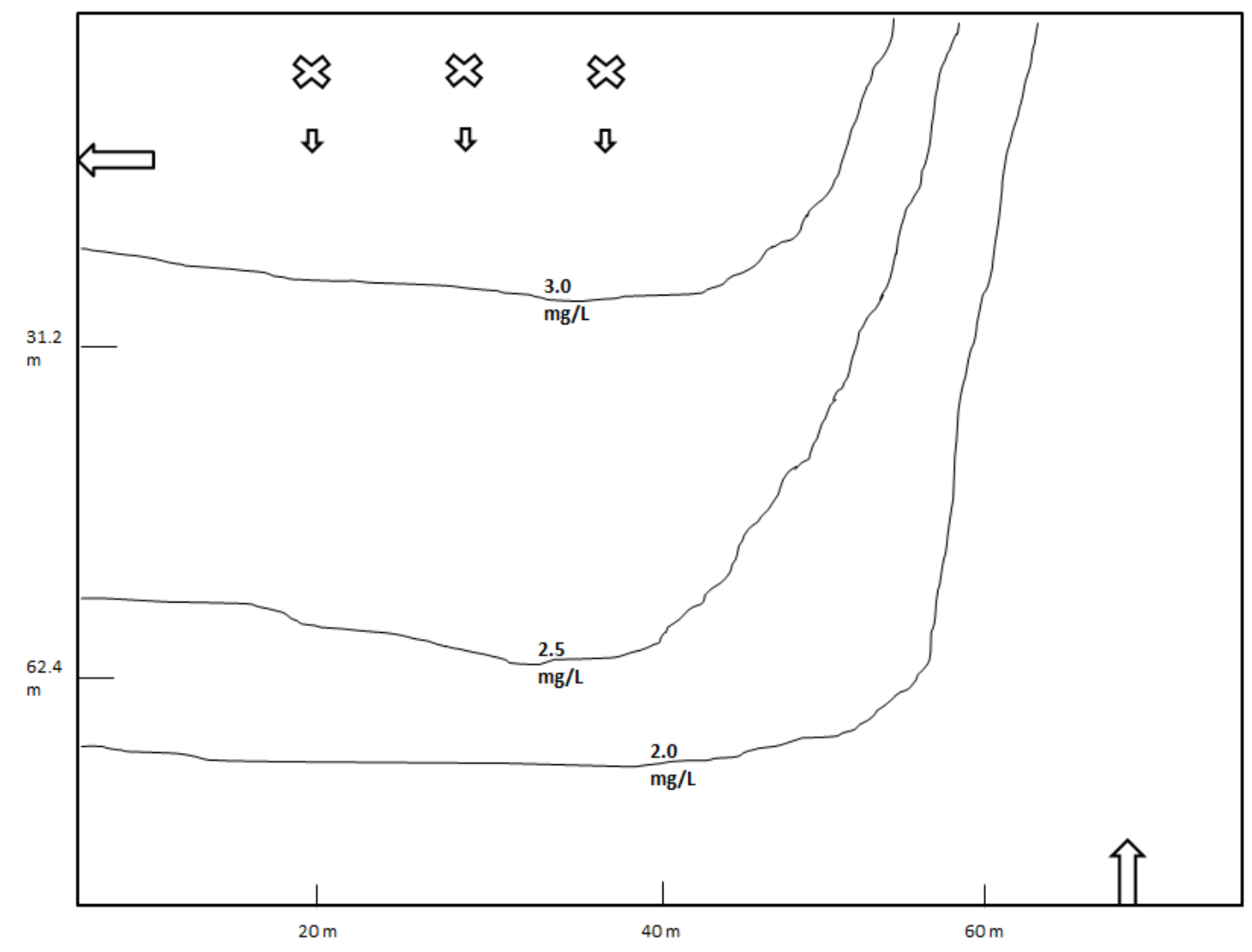

Figure 4.Oxygenation zone pattern for Split Pond 2 at 5:00 AM in July. Large arrows represent the inflow and outflow of the split pond sluiceways. 


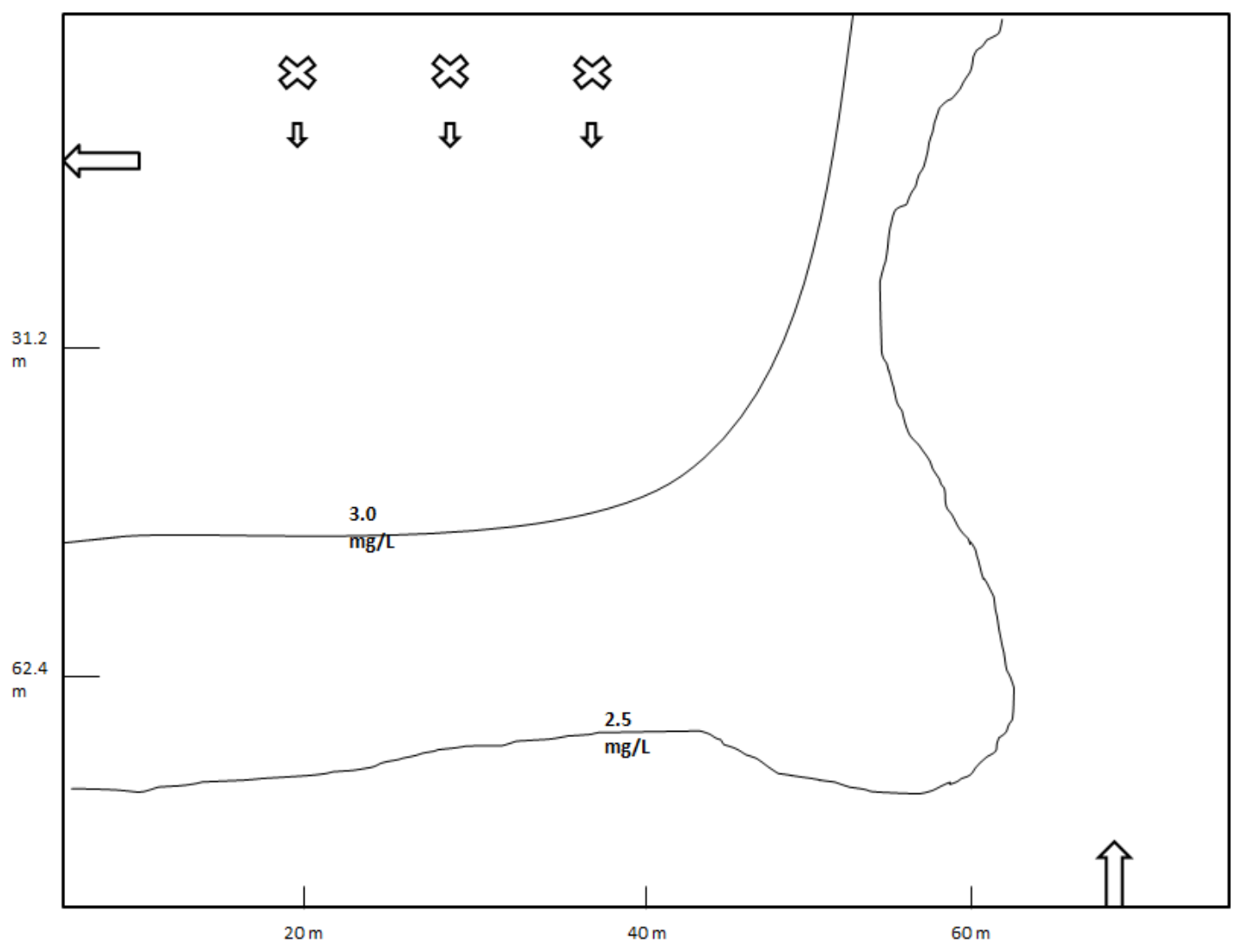

Figure 5.Oxygenation zone pattern for Split Pond 2 at 12:00 AM in July. Large arrows represent the inflow and outflow of the split pond sluiceways. 


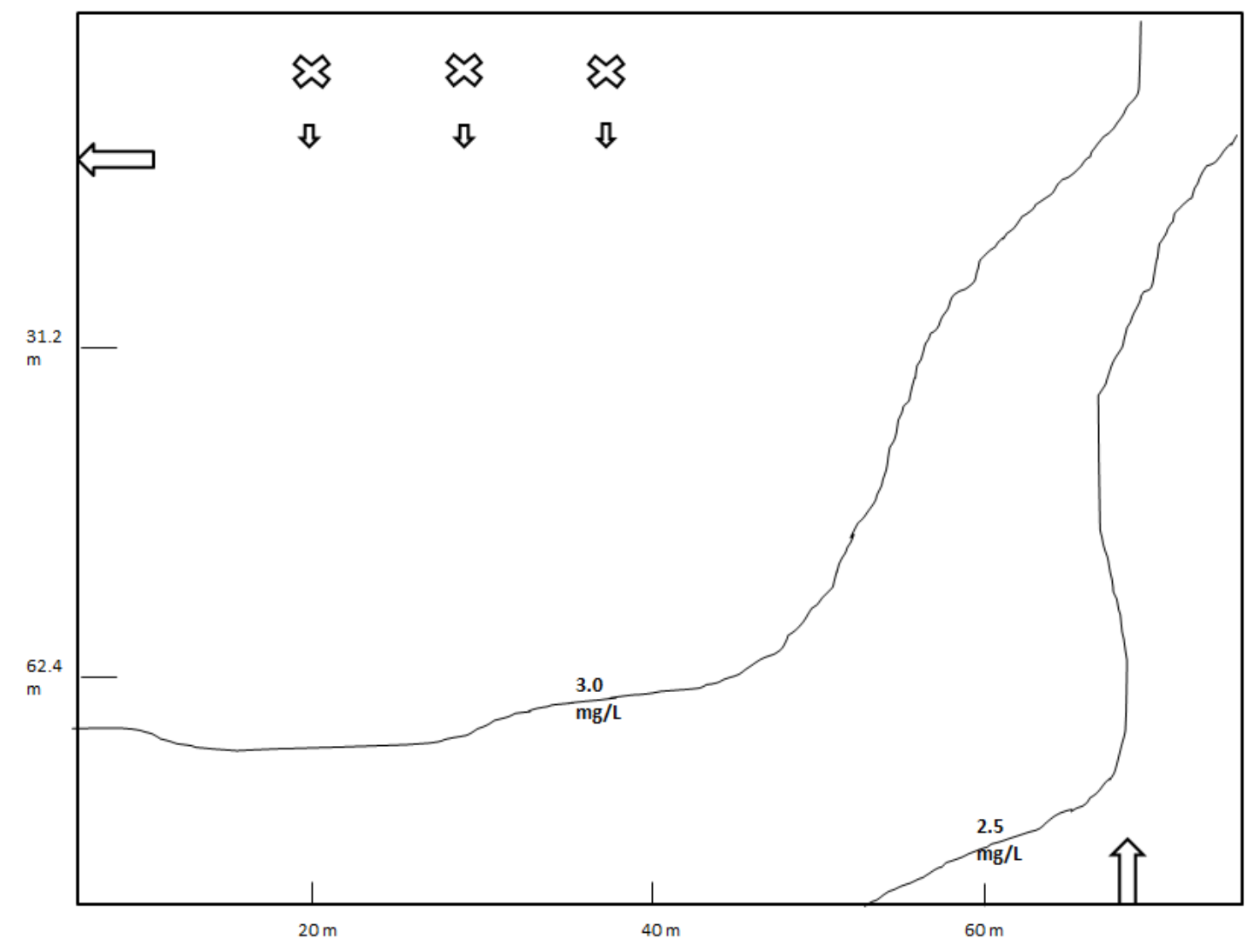

Figure 6.Oxygenation zone pattern for Split Pond 2 at 9:00 AM in July. Large arrows represent the inflow and outflow of the split pond sluiceways. 